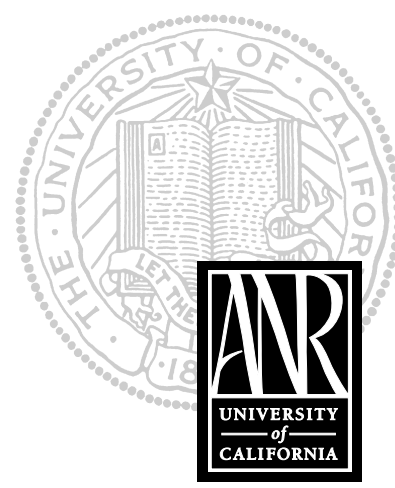

UNIVERSITY OF CALIFORNIA

Division of Agriculture and Natural Resources

http://anrcatalog.ucdavis.edu

\title{
Plasticulture in California Vegetable Production
}

\author{
WAYNE L. SCHRADER, UC Cooperative Extension Vegetable Farm Advisor, San \\ Diego County
}

Plasticulture is the art of using plastic materials to modify the production environment in vegetable crop production. Plasticulture began in the 1950s and early 1960s with the introduction and use of plastic films, mulches, and drip irrigation systems. Vegetable growers frequently use plastics in pest management, stand establishment, harvesting, and postharvest handling operations, and in containers for marketing.

Plasticulture system components can include

- plastic mulches to control soil temperature, control weeds, and repel insects

- plastic films for erosion control, soil fumigation, or solarization

- row covers for temperature control, wind or frost protection, and insect exclusion

- drip irrigation for improved water management and for the application of chemicals (chemigation) and fertilizers (fertigation) during irrigation

- plastic windbreaks

- plastic barriers against vertebrate pests

Plasticulture has developed into management systems that allow growers to achieve higher-quality produce, superior yields, and extended production cycles. Growers using plasticulture can produce vegetables for markets during the winter, early spring, and late fall that would otherwise be impossible to address.

Benefits of plasticulture include

- earlier production (7 to 30 days earlier)

- increased yields (up to 4 times higher)

- higher-quality and cleaner produce

- efficient water use (savings up to $80 \%$ )

- efficient fertilizer use (savings up to 50\%)

- more effective wetted areas in light soils

- reduction in weeding (up to $100 \%$ reduction)

- management of some insect pests

- control of many soilborne disease pathogens

- reduction in soil erosion by water or wind

- double or triple cropping of valuable vegetable production soils

\section{PLASTIC MULCHES}

Plastic films applied to cover the soil (plastic mulches) are commonly used to modify soil temperatures, exclude light for weed control, conserve water, protect fruit from contact with soil moisture and pathogens, repel certain insects, and control erosion. Plastic agricultural mulches in the United States are usually made of highdensity polyethylene sheeting from 1 to 3 mils in thickness, 40 to 70 inches wide or more, and on rolls up to 5,000 feet in length. The plastic film may be smooth or embossed with a continuous diamond pattern that reduces its expansion and contraction during daily heating and cooling. Mulches are used both on raised beds of various sizes and on flat ground beds. All plastic mulches help conserve soil moisture and control soil erosion. The cost of mulch use in vegetable production varies 
based on the efficiency of the installation crews, the type of plastic selected, and the price per pound of plastic. At the time of this writing, plastic mulch that is $1.5 \mathrm{mil}$ thick and 4 feet wide on 60 -inch beds costs approximately $\$ 400$ per acre.

Mulch color and clarity determine the plastic film's surface temperature during the day and the degree to which the mulch will affect soil temperatures. Table 1 relates how different mulches affect soil temperatures during the night and day. On sunny days, black plastic mulches have a high surface temperature that can burn fruit or leaves that come in contact with the mulch. Black mulches can have either little effect or an intense heating effect on soils depending on the degree of contact between the mulch and the moist soil surface. If the black plastic is stretched tight over a smooth bed and is in intimate contact with the smooth bed top, heating can be significant. Soil temperatures under black plastic are typically $5^{\circ} \mathrm{F}$ higher at a 2inch depth and $3^{\circ} \mathrm{F}$ higher at a 4-inch depth than those of bare soil at the same depths. If the soil under black plastic is bumpy, intimate contact is not achieved and the black plastic will shade the soil. Soil heating in this case will be greatly reduced.

Table 1. Effect of plastic mulch color on soil temperature, as compared to unmulched soil.

\begin{tabular}{lcc}
\hline \multicolumn{3}{c}{ Relative temperature of mulched soil } \\
\cline { 2 - 3 } Mulch color & Nighttime & Daytime \\
\hline Clear & warmer & warmer \\
Black & warmer & warmer \\
White & warmer & cooler \\
Reflective & warmer & cooler \\
\hline
\end{tabular}

Clear plastic mulches have a cooler surface temperature than black mulches, but heat soils more during the day. Soil temperatures under clear plastic are typically $10^{\circ}$ to $14^{\circ} \mathrm{F}$ higher at a 2 -inch depth and $6^{\circ}$ to $9^{\circ} \mathrm{F}$ higher at a 4-inch depth than those of bare soil. Clear plastic mulches transmit the wavelengths of light necessary for photosynthesis to the soil surface, allowing weeds to grow under the mulch unless the soil has been fumigated or appropriately solarized. Even with fumigation or solarization, certain weed seed (including field bindweed, little mallow, California burclover, black medic, and yellow sweetclover) often escape fumigation and germinate under clear mulches. Strawberries in California typically are mulched with clear plastic during the winter to help warm the soil. In strawberry production the mulch is applied 1 to 2 weeks after transplanting. Workers apply the plastic over each row and use a butane burner to cut a hole through which each plant can be pulled and can grow.

Infrared-transmitting (IRT) film mulches are an attempt to combine the benefits of both clear and black mulches. IRT films are engineered to absorb photosynthetic wavelengths that foster weed growth, but allow the infrared light through to heat the soil. Soil temperatures under IRT plastic films typically fall between the ranges for black and clear film mulches. Some IRT films do a good job of meeting these two goals. Others, however, fail to block the appropriate photosynthetic wavelengths and vary in their ability to prevent weed growth and to provide soil heating.

Colored plastic mulches being investigated for vegetable production include yellow, orange, red, blue, and gray films. These materials reflect different light wavelengths into the canopy of the vegetable crop in an attempt to affect plant growth and development. Colored mulches change reflected light wavelengths that can affect the growth and yield characteristics of plants. Colored mulches have a demon- 
strated ability to alter crop growth and yield patterns in controlled conditions. Field trials with these mulches, however, have yielded inconsistent results. Yellow, red, and blue mulches have also been shown to increase populations of green peach aphids and cucumber beetles during early crop production.

Reflective (silver-colored or aluminum-coated) plastic mulches can stimulate higher rates of photosynthesis by increasing the intensity of active light wavelengths in the lower canopy. Strongly reflective mulches may cause burning and desiccation of transplants in midsummer plantings. Reflective mulches have been used successfully to reduce and delay the incidence of aphid and whitefly colonization in vegetable crops and to delay the onset of aphid-borne virus diseases. Reflective mulches have also been shown to repel corn stunt leafhopper, with the result of increased growth and yield of sweet corn. Reflective mulches cease to repel insects, however, after the plant canopy covers 60 percent of the mulch surface. The delay of colonization of aphids in squash and cucumber production fields caused by reflective mulches may mean the difference between some production and the total loss of a field.

Spray-applied synthetic latex mulches are currently being tested by manufacturers as an alternative to plastic film mulches. These biodegradable, water-dispersible spray mulches are easier to apply than plastic films and can be incorporated into the soil at the end of the season. This eliminates the need to remove the plastic at the end of the season and to dispose of used plastic mulch films in landfills. Spray mulches do not inhibit weed growth and must be used in conjunction with herbicide applications. They are also destroyed through cultivation or other disruption of the soil surface.

Photodegradable and biodegradable plastic mulches can eliminate the need to remove plastic at the end of the season as well as the cost of sending plastic waste to the landfill. Degradable films often give the same benefits as standard plastic mulches. Unfortunately, degradable films are sometimes problematic in the length of time they take to degrade. Photodegradable films depend on sunlight for degradation, so the portion of the film that is covered by soil to hold it down does not degrade. Strips of this undegraded mulch are left in the field after disking and field cleanup. Neighbors to production fields often complain about the thousands of small pieces of degrading film that blow in the wind near the end of the season. Also, degradable plastic films sometimes degrade while they are still needed for crop protection. If you use degradable films, take care to find films (through repeated, smallscale trials on your farm) that work consistently within a production system.

\section{SOIL SOLARIZATION}

Soil solarization is a soil heating and disinfestation process that is accomplished through the passive capture of solar radiation in moist soil covered with clear plastic mulch. It is used as a substitute for synthetic chemical fumigants and its use is expected to increase as methyl bromide use is phased out. It is generally restricted to areas where air temperatures are very high during the summer and cropland is rotated out of production due to excessive heat. Soil solarization is compatible with other disinfestation methods such as organic amendments (cruciferous crop residues, etc.), biological control organisms, or the use of pesticides. Research has shown that over 40 fungal pathogens, 25 species of nematodes, numerous weeds, and some bacterial pathogens are controlled or partially controlled with soil solarization. This is one of the reasons that an increased growth response is often observed after solarization. Solarization also increases the availability of soluble mineral nutrients following treatment. 
The process of soil solarization is fairly simple. The area to be solarized should be level and free of weeds, debris, or large clods that could raise the plastic off the ground. Clear plastic films 1 to 4 mils ( 0.001 to 0.004 inch) thick are anchored to the soil by burying the edges in small ditches around the treated area. Soil under the plastic is then soaked with water via one or more hoses or pipe outlets inserted under one end of the tarp. The soil may be irrigated before you lay the plastic, but the plastic should be applied immediately after irrigation in order to avoid water loss. The plastic should be left in place for 4 to 6 weeks to allow the soil to heat to the greatest depth possible. The principal mode of action is direct thermal inactivation of soilborne pathogens and pests. The "heat dosage" of solarization (heat $\times$ time) is affected by several factors. Soil solarization is most effective when day and night temperatures are high, solar radiation is intense, air is still and clear (clouds and wind reduce heating), soil is dark in color (darker soils absorb more heat), heavier (soils with more clay particles tend to retain more heat), and moist (moist soils allow heat transfer), and when clear plastics are used. Soil moisture is extremely important. Soil that is moist rather than dry prior to solarization will stimulate microorganisms to break dormancy from their survival structures, making them more susceptible to the biocidal effects of the heat treatment.

\section{WALK-IN TUNNELS}

Walk-in tunnels are low-cost Quonset-shaped or rectangular buildings consisting of a wooden, polyethylene pipe, metal pipe, or tentlike rope and stake framework covered with greenhouse plastic sheeting ( 4 to 6 mils thick). Many designs, ranging from semi-permanent greenhouses to lightweight moveable frames, have been developed over the years. These structures are used to produce vegetables and herbs during the winter months. Larger structures are usually oriented north-to-south and have rectangular hinged doors at each end. The doors are large enough to allow a small tractor and tillage equipment in for soil preparation. Planting is normally done directly into the soil without the use of containers or planting media. The increase in air temperature inside a walk-in tunnel can be up to $30^{\circ} \mathrm{F}$ during the day and up to $15^{\circ} \mathrm{F}$ during the night in winter months. This temperature increase is generally adequate to protect vegetable crops from frost damage without supplemental heating. Passive supplemental heating can be supplied by placing black metal drums filled with water along the walls of the structure.

\section{ROW COVERS OR TUNNELS}

Row covers are plastic tunnels that cover individual rows of vegetable crops in the field. These row covers or tunnels may use wire hoops, apical wires, and two sheets of plastic to produce rigid tunnels that hold up well in wind. Some use plastic or wire hoops alone to support a single sheet of plastic film, and others are full floating row covers where one sheet of spun bond polyester material rests directly on the crop as it grows. Row covers increase the temperature around vegetables grown in the winter months but they also increase humidity around the plants. Higher humidity around the plants usually increases the need for fungicide applications to prevent disease problems. The cost of row covers and tunnels varies based on the efficiency of the installation crews, the types of plastics selected, and the price per pound of plastic. The approximate per-acre cost for plastic tunnels, including labor, is $\$ 950$ for a 1.5 mil rigid tunnel on 60 -inch beds. 
Air temperature usually increases from $6^{\circ}$ to $20^{\circ} \mathrm{F}$ inside an enclosed row cover at midday, depending on the type of tunnel and materials used. Soil temperatures are raised $4^{\circ}$ to $8^{\circ} \mathrm{F}$ in the daytime to a depth of 3 inches. Heat energy stored in the soil moisture during the day is released at night and is held in a plastic tunnel by the water that condenses on the inside of the row cover. This same principle keeps night temperatures higher on cloudy nights. The more soil area that is covered by clear plastic, the greater the amount of heat energy that can be stored in the soil.

Tunnels that cover a large percentage of the soil will give the greatest level of temperature increase in the field. Tunnels can be used over bare soil or with perforated clear plastic mulch for extra soil heating. When working with row covers, remember that the warmest part of the tunnel is at its center and that moisture must condense on the inside of the tunnel to keep the tunnel warm at night.

Too much heat in the tunnel can be as much of a problem as too little. Row covers are frequently constructed using perforated plastic sheeting. This kind of builtin venting allows firmer plant growth and prevents excessive midday temperatures. Amazingly, the perforations do not prevent the condensation of moisture in the tunnel that helps keep the plants warm at night.

Crops grown commercially under tunnels are generally drip irrigated. Plastic tunnels alone give little frost protection in the early morning hours. Row covers combined with drip irrigation, however, yield greater frost protection. By running the drip irrigation system during periods of frost danger, you release heat into the tunnel and protect the plants.

\section{RIGID-TUNNEL ROW COVERS}

Rigid-tunnel row covers have been used in coastal southern California where high winds can tear apart less sturdy row covers. The following materials and equipment are needed to build rigid, two-sided row covers or tunnels:

1. plastic-laying apparatus

2. 1.5 to 3.0 mil clear plastic sheeting 36 inches wide with a haze factor of 12 to 20 percent (solid or perforated with $1 / 4$-inch holes 3 inches apart)

3. wire hoops, 9 gauge and 70 inches long

4. strong clothespins

5. rolls of 16 gauge wire

6. heavy-duty staple gun

7. 1 inch $\times 1$ inch in-row stakes (stake height depends on crop)

8. 2 inch $\times 3$ inch anchor stakes for ends of rows

Note that 60 -inch rows require 18,000 feet of plastic sheet per acre. Tunnel materials usually are placed in the fields well in advance of planting to avoid rain delays and ensure planting on the desired date. To avoid wind damage, the plastic sheets are pinned down to the soil level until needed with the same clothespins that will secure the two sheets to the apical wire at planting.

Row covers for staked tomatoes are made with two sheets of plastic laid 26 to 28 inches apart down the center of 60- to 72-inch rows with 6 to 8 inches of one edge of each sheet anchored into a small ditch in the soil. Six-foot stakes are spaced three to four feet apart in the center of the bed. A 16 gauge apical wire is stapled to the stakes at a 20 to 22 inch height and tied to anchor stakes at the ends of each row. Nine gauge semicircular wire hoops, 70 inches long, are placed over the apical wire at alternate stakes and forced into the ground just inside the plastic sheets to cover an area 26 to 28 inches wide. The plastic sheets are pulled up to cover the hoops 
forming a tunnel. At the top of the row cover, the two sheets overlap by 3 or 4 inches and are fixed to the apical wire with strong clothespins. Three or four pins are used between stakes.

Row covers for cucumbers and squash are similar to those used for staked tomatoes. These crops, however, are grown as bush plantings and so do not require tall stakes. Stakes 1 inch by 1 inch by 26 inches long are driven into the ground, giving a row cover height of 16 to 18 inches. These stakes are spaced 10 to 15 feet apart in the rows. A 16 gauge apical wire is stapled to the top of the stakes. Hoops are spaced 4 to 8 feet apart down the rows to form the tunnel shape and to keep the plastic taut. The same type and width of plastic is used and secured to the apical wire with clothespins.

In windy areas, row covers should be constructed with an extra hoop placed above the plastic over each bottom hoop. This top hoop keeps the plastic from flapping and tearing in the wind. Where severe winds are a problem, coated wire twists are used to secure the top hoop, bottom hoop, and apical wire together. This reinforced construction has weathered even moderately heavy storms.

Venting and temperature management in rigid row covers are accomplished through venting. The two-sheet construction permits the clothespins to be released and one side of the cover to be dropped down for weeding, pesticide application, or other cultural operations. Venting is accomplished by pinning the top edge of the row cover back to the hoops. In this way a 1- or 2-inch triangular opening can be made at each hoop for early venting, and this top space widened as the plants grow or as seasonal spring temperatures rise. Later in the season, both sides of the plastic are moved down the wire hoops until the entire row cover is open at the top. Where row ends face into the wind or where tunnels are on a slope, the tunnel ends can be opened for venting. Most row covers are constructed using one or two perforated plastic sheets. This provides built-in venting which allows firmer plant growth and prevents excessive midday temperatures.

Optimal temperatures for warm-season crop plant growth and quality fruit production are $65^{\circ}$ to $85^{\circ} \mathrm{F}$. By venting or closing the tunnels, you can control temperatures within the row covers. When possible, tunnel temperatures should not be allowed to fall below $60^{\circ}$ to $65^{\circ} \mathrm{F}$ or exceed $80^{\circ}$ to $90^{\circ} \mathrm{F}$. Sustained temperatures below $55^{\circ}$ to $60^{\circ} \mathrm{F}$ may lead to chilling injury of many warm-season crops. Temperatures above $90^{\circ} \mathrm{F}$ can cause flowers to abort (drop).

In tomato production, 3 or 4 weeks after planting, one plastic sheet is dropped and pruning (removal of the bottom side shoots) is completed. Spraying, weeding, and tying to the stake are carried out at the same time and the tunnel re-closed. When plants develop functional flower clusters, the cover is vented to allow wind pollination or flowers are vibrated to help establish the crown set. Depending on climatic conditions, the cover may be vented four to eight separate times in the process of opening the row covers. If temperatures are too low for natural fruit setting, you can use plant growth regulators to spray clusters and establish fruit set. When harvesting begins, the two plastic sheets are dropped to the ground where they are used as a soil mulch for several weeks.

Cucumbers are more susceptible to cold injury than tomatoes or peppers, and venting is delayed to 50 to 70 days after seeding. The plants usually fill most of the inside of the covers before venting begins. Small $V$ vents are opened at each hoop a 
few days before first harvest. At the completion of the second harvest, both sheets are lowered 3 to 6 inches on the hoops. After three to four harvests, the plastic is moved to a double windbreak by placing the hoops lengthwise along each side of the rows and securing the plastic to them. These windbreaks protect the plants from foot traffic as well as wind and are left up until harvesting ends.

In pepper production, venting begins within 4 to 5 weeks after transplanting and tunnels are opened more rapidly as flowers develop on the plants. The plants' need for flower pollination via air movement and insects necessitates either this earlier opening or the vibration of flowers for early fruit set. As the venting area is increased and opened on both sides of the cover, the retracted sheets are used as windbreaks as in cucumber production.

Nearly all of the crops grown commercially under tunnels are drip irrigated. A small furrow near the drip line inside the tunnel usually channels away excess moisture during rains. This furrow helps to prevent the washing out of tunnel sides. Plastic row covers alone generally give little frost protection in the hours just before dawn. When combined with drip irrigation, however, row covers provide several degrees of protection. During frost conditions, drip irrigation releases heat within the tunnel and protects plantings.

\section{HOOP-SUPPORTED ROW COVERS}

Where high winds generally are not a problem, growers use hoop-supported row covers. The stakes and apical wires are eliminated and wire hoops alone are used to support the plastic row covers. A single, wider sheet of plastic is used and one edge of the sheet is anchored by soil in a small ditch. Nine gauge wire hoops of a length appropriate for the size of the row cover are placed next to the buried plastic to form arches over the planted row at intervals of approximately 3 feet. When pulled up to cover the hoops, the plastic sheet forms a tunnel. Anchor stakes at the row ends and heavy plastic string of a type that will not deteriorate or stretch when wet can be used to form a stronger tunnel: the string is tied to the anchor stakes and wound around each hoop for an apical support. This helps to keep the hoops vertical and in place. Additional wire hoops are placed over the top of the tunnel at every internal hoop or at alternate hoops to hold the plastic sheet down and keep any wind from damaging the tunnels. Tunnels can be opened for cultural work or spraying by pulling the loose end of the plastic up between the hoops. The loose end of the plastic is usually pinned down to the soil when closed.

\section{FLOATING ROW COVERS}

Another option is the floating row cover, a one-piece cover of spun bond polyester materials placed in the field without supporting hoops or stakes. Floating row covers "float" or rest on top of the crop as it grows, and are often used to increase early growth and to exclude insects that transmit viruses. Floating covers reduce installation costs and venting labor by about 80 percent, but they also reduce the extent of temperature protection. Temperatures under clear poly covers generally range $2^{\circ}$ to $3^{\circ} \mathrm{F}$ warmer than under floating spun bond fabrics. With moderate weather and sunny days there is little difference between bonded materials and clear poly covers. If the weather is cool, however, clear poly gives a temperature advantage.

Row-cover materials vary in their ability to transmit light and heat energy to the soil and maintain above-ambient temperatures at night. All covers increase daytime temperatures. Bonded fabrics, however, generally allow about 10 percent less light energy to reach the soil than clear plastic covers. Polyethylene allows more heat radi- 
ation to escape at night than do polypropylene materials. Porous bonded materials also transfer heat out of row covers through air mixing. This is probably why these materials appear to be less effective under windy conditions.

\section{DRIP IRRIGATION}

Drip irrigation enables growers to provide continuous wetting directly to the root zone along vegetable rows via drip tape. This technology makes it possible to irrigate vegetable crops under plastic mulches and tunnels. Drip tape generally is 3 to 8 mils thick and usually is used for one year and discarded. Heavier drip tubes with in-line emitters can be retrieved and reused over many seasons. Studies have shown that drip irrigation can save up to 80 percent of the water that is required by other irrigation methods. Besides increasing water efficiency, drip irrigation systems allow the grower to place nutrients (fertigation) and chemicals (chemigation) directly into the root zone. Fertigation has enabled growers to reduce their fertilizer use and the leaching of nutrients below the root zone by as much as 50 percent.

\section{PLASTIC WINDBREAKS AND VERTEBRATE PEST BARRIERS}

Plastic windbreaks and pest barriers are useful in areas prone to wind, rain, hail, and vertebrate pest damage. Windbreaks and pest barriers are erected using wooden stakes, plastic sheeting, string, and clothespins. Pest barriers are constructed at the edges of a field by burying one edge of a length of black plastic sheeting into the soil as with rigid plastic tunnels. Stakes are pounded into the ground inside the barrier at the same intervals used in the construction of rigid plastic tunnels. String is wound around the stakes and the plastic is pulled up to the string, wrapped over, and pinned to the string with clothespins. The black plastic prevents rodents from seeing the crop, and the stakes are placed inside the plastic so rodents will not be able to climb them. Gates for easy access to the field are made by overlapping lengths of the barrier and leaving a big enough space between the overlapped lengths for a person to walk through. In general, squirrels and rodents will not pursue what they cannot see. Windbreaks (half-tents) are constructed with clear plastic and erected to the windward side of every vegetable row, slanted over the crop, for added protection from rain or hail in the early spring.

\section{RECYCLING PLASTIC MATERIALS}

Most agricultural plastics are sent to landfills after use, and a small percentage are being recycled. The problems associated with recycling are the cost of recovery and transportation, the contamination of plastics with soil, plant materials, and pesticide residues, and a lack of information on companies that are actively recycling agricultural plastics. Agricultural plastics vary greatly in the quality of resin used for their production and the degree of degradation resulting from the passage of time and the material's exposure to sun and diurnal temperature changes. Nursery pots are manufactured using post-consumer plastics and industrial scrap plastics. Most recycling occurs in the greenhouse production of vegetable transplants, where plastic trays are repeatedly cleaned and reused. Some tunnel and floating row-cover materials are reused by growers until ultraviolet light damage causes them to split and tear. 


\section{REFEREN CES}

Vegetable Production Using Plasticulture. 1998. W. J. Lamont et al. Alexandria: ASHS Press, American Society for Horticultural Science.

Influence of sprayable mulch colour on yield of eggplant (Solanum melongena L.). 1997. M. A. Mahmoudpour and J. J. Stapleton. Scientia Horticulturae 70:331-38.

Management of aphids, silverleaf whiteflies, and corn stunt leafhoppers using reflective plastic mulch and insecticides. 1998. C. G. Summers and J. J. Stapleton. Kearney Agricultural Center Plant Protection Quarterly. 9:2-7.

Solarization: An implementable alternative for soil disinfestation. 1997. J. J. Stapleton. Biological and Cultural Tests for Control of Plant Diseases. 12:1-5.

\section{FOR MORE INFORMATION}

You'll find detailed information on many aspects of commercial vegetable production in these titles and in other publications, slide sets, and videos from UC ANR:

Commercial Greenhouse Vegetable Handbook, publication 21575

Soil Solarization: A Nonpesticidal Method for Controlling Diseases, Nematodes, and Weeds, publication 21377

Specialty and Minor Crops Handbook, publication 3346

To order these products, visit our online catalog at http://anrcatalog.ucdavis.edu. You can also place orders by mail, phone, or fax, or request a printed catalog of publications, slide sets, and videos from

University of California

Division of Agriculture and Natural Resources

Communication Services

6701 San Pablo Avenue, 2nd Floor

Oakland, California 94608-1239

Telephone: 1-800-994-8849 or (510) 642-2431, FAX: (510) 643-5470

e-mail inquiries: danrcs@ucdavis.edu

An electronic version of this publication is available on the DANR Communication Services website at http://anrcatalog.ucdavis.edu.

Publication 8016

(C) 2000 by the Regents of the University of California, Division of Agriculture and Natural Resources. All rights reserved.

The University of California prohibits discrimination against or harassment of any person employed by or seeking employment with the University on the basis of race, color, national origin, religion, sex, physical or mental disability, medical condition (cancer-related or genetic characteristics), ancestry, marital status, age, sexual orientation, citizenship, or status as a covered veteran (special disabled veteran, Vietnam-era veteran or any other veteran who served on active duty during a war or in a campaign or expedition for which a campaign badge has been authorized).

University Policy is intended to be consistent with the provisions of applicable State and Federal laws.

Inquiries regarding the University's nondiscrimination policies may be directed to the Affirmative Action/Staff Personnel Services Director, University of California, Agriculture and Natural Resources, 1111 Franklin, 6th Floor, Oakland, CA 94607-5200 (510) 987-0096. For information about downloading this publication, telephone (530) 754-5112.

pr-11/00-WJC/WS

ISBN 978-1-60107-196-5 